\title{
Letter to the Editors regarding the paper: Sociodemographic Characteristics of Indigenous Population According to the 2000 and 2010 Brazilian Demographic Censuses: A Comparative Appro- ach
}

\author{
Carta a las Editoras sobre el artículo: Características \\ Sociodemográficas de Indígenas en los Censos \\ Brasileños de 2000 y 2010: Un Enfoque Comparativo
}

\author{
Carta às Editoras sobre o artigo: Características Sociodemográficas \\ de Indígenas nos Censos Brasileiros de 2000 e 2010: Uma \\ Abordagem Comparativa
}

doi: 10.1590/0102-311X00199317

We have read with interest the article regarding sociodemographic characteristics of indigenous populations 1 and wanted to mention the importance of the studies on these inhabitants and share data from a neighboring country: Peru.

Peru and Brazil belong to the small group of countries that have indigenous populations with no contact inside their territory. These people live in the Amazon Rainforest, which is shared by eight countries. Their similarities include: poor access to health care, poor level of education, higher mortality rates, lower life expectancy and different immune responses to the non-indigenous population 2,3.

Most of these people reside in territorial reserves protected by the state. That is one of the main reasons why regular people do not have access to them. As a consequence, the data is not updated frequently. We have reviewed some data from indigenous populations in Peru between the years 1993 to 2007. This information is from the 2003 Health Situation Analysis of Indigenous Populations of the Peruvian Amazon 4, and the 2007 censuses (http://censos.inei.gob.pe/cpv2007/tabulados/): XI of population, VI of living place and II indigenous populations of Peruvian Amazon.

According to the 2007 censuses, 332,975 people belong to ethnical minorities nationwide. In 1993, the population of children less than 15 years old was 49.7\%; 15-64 years, 48.8\%; and with more than 64 years, $1.5 \%$. Ten years ago, the numbers changed to $47.5 \%, 50.6 \%$, and $1.9 \%$ respectively (Table 1 ). This data reveals that their life expectancy is lower than the non-indigenous population of the country 4,5 .

Likewise, the last census states that $47.3 \%$ of the population older than 15 years old finished at least a few academic years in elementary school; and, 28.7\% in high school; unlike 1993, when only $17 \%$ had finished some academic years. According to 2003, the school attendance rate for the group aged from 6 to 11 years is $75 \%$, and for the group from 12 to 17 years is $62 \%$. Likewise, the common year of school dropout is the 3rd year of elementary school. Illiterate population represents $19.4 \%$ of the population. This last condition affects the female population more $(28.1 \%)$ than the male one $(11.8 \%) 4,5$.

The total of the economically active population is 11,061 people: $97.1 \%$ of them are occupied and $2.9 \%$ unoccupied. From the occupied people, 52\% are independent workers, $23.9 \%$ unpaid family workers, $15.8 \%$ workers, $6.1 \%$ employees, $1.4 \%$ employers and $0.8 \%$ housekeepers 4,5 . 
Table 1

Summary of the age distribution.

\begin{tabular}{lcc}
\hline Age bracket (years) & \multicolumn{2}{c}{ Census } \\
& $\mathbf{1 9 9 3}$ & $\mathbf{2 0 0 7}$ \\
\hline$<15$ & $49.7 \%$ & $47.5 \%$ \\
$15-64$ & $48.8 \%$ & $50.6 \%$ \\
$64+$ & $1.5 \%$ & $1.9 \%$ \\
\hline
\end{tabular}

Source: elaborated by the authors, using data from the Peruvian Ministry of Health 4 and Peruvian Institute of Statistics and Informatics 5 .

Finally, we praise your interest in investigating this kind of population, which tends to be abandoned in research. It is a pleasure to share this information to support your research and we hope to create more data of indigenous populations for new health plans.

Alfredo Casella-Fernández 1

Daniela Limas-Haro 1

Aldo Lucchetti 1,2

1 Universidad Peruana de Ciencias Aplicadas, Lima, Perú.

2 Hospital Nacional Arzobispo Loayza, Lima, Perú.

\section{Contributors}

A. Casella-Fernández and D. Limas-Haro wrote the article. A. Lucchetti reviewed and approved the final version of the article to be published.

\section{Acknowledgments}

Special thanks to Ms. Tania Rengifo for language editing. 
1. 1. Bastos JL, Santos RV, Cruz OG, Longo LAFB, Silva LO. Sociodemographic characteristics of indigenous population according to the 2000 and 2010 Brazilian demographic censuses: a comparative approach. Cad Saúde Pública 2017; 33 Suppl 1:e00085516

2. Naciones Unidas. Pueblos indígenas. http:// www.un.org/es/globalissues/indigenous/ (accessed on 14/Oct/2017).

3. Organización Panamericana de la Salud. Salud de los pueblos indígenas. http://www.paho.org/chi/index.php?option $=$ com $m_{-}$content $\& v$ ie $w=a r t i c l e \& i$ $\mathrm{d}=83$ :salud-pueblos-indigenas \&Itemid $=213$ (accessed on 28/Oct/2017).

4. Ministerio de Salud del Perú. Análisis de la situación de los pueblos indígenas de la Amazonia Peruana. Lima: Oficina General de Epidemiología; 2003.

5. Instituto Nacional de Estadística e Informática. Población indígena de la Amazonía peruana supera los 330 mil habitantes. https://www.inei.gob.pe/prensa/noticias/poblacion-indigena-de-laa m a z o n i a - p e r u a n a - s u p e $\mathrm{r}$ a -1 o s $-330-\mathrm{m}$ i l $-\mathrm{h}$ a b i t a $\mathrm{n}$ tes-9232/ (accessed on 31/Oct/2017). 